\title{
SILEK KUMANGO: KEBERADAAN, PEWARISAN, DAN KEARIFAN LOKAL MINANGKABAU
}

\section{Isral Saputra}

\begin{abstract}
Nowadays, the Minangkabau silek is waning interest and users. Technological developments are considered to be the cause. This article describes the research result of the presence of silek Kumango in Kanagarian Rao-Rao Tanah Datar, West Sumatra. Using ethnographic methods and approaches, it's also obtained the inheritance and local genius in this silek. There are some functions and symbols that show local content in silek Kumango which are manifested in the succession process, control, and motion itself in this silek.
\end{abstract}

Key word: silek, Kumango, Minangkabau, Tanah Datar, ethnography

\section{Latar Belakang}

Setiap daerah di Indonesia memiliki istilah-istilah yang berbeda tentang pencak silat. Pencak Silat di Jawa Barat disebut dengan maempok dan pencak, sedangkan di Jawa Tengah dan Jawa Timur disebut pencak. Di Madura, Pulau Bawean, dan Bali pencak silat disebut dengan mancak di Nusa Tenggara Barat disebut mpaa silak. Pencak silat di Bulungan Kalimantan Timur, disebut bemancek, dan di Minangkabau disebut dengan silek dan gayuang.

Di Minangkabau, sampai saat ini belum diketahui secara pasti siapa awalnya yang menciptakan seni bela diri pencak silek. Silek di Minangkabau telah dimiliki dan dikembangkan oleh salah seorang penasehat Sultan Sri Maharajo Dirajo yaitu seorang raja di Kerajaan Pariangan (Maryono, 1998:40). Menurut ceritanya, di sebelah tenggara kaki Gunung Merapi bermukim seorang penasehat raja Pariangan yaitu Datuak Suri Dirajo. Beliau menciptakan silek Minangkabau di samping mengembangkan bermacam-macam kesenian, seperti tari-tarian yang diangkat dari gerakan 
silek dan pembuatan peralatan musik seperti talempong, gong, gendang, serunai, dan lain-lain.

Datuak Suri Dirajo mewariskan silek kepada empat pasukan pengawal Sultan Sri Maharajo Dirajo. Pengawal-pengawal tersebut bernama Kuciang Siam, Harimau Campo, Kambiang Hutan, dan Anjiang Mualim. Kuciang Siam adalah seorang pengawal berasal dari kawasan Kucin- Cina (Siam), sekarang Thailand. Harimau Campo adalah seorang pengawal yang berasal dari kerajaan Campa, kawasan Kamboja dan Vietnam Selatan. Kambiang Hitam adalah seorang pengawal yang berasal dari kerajaan Khemer (Siamrep) di tepi Danau Tunlesap kawasan Utara Kamboja, dan Anjiang Mualim adalah seorang pengawal yang datang dari kawasan Persia atau Gujarat. Keempat pengawal ini sebetulnya sudah mempunyai keahlian bela diri dari masing-masing negerinya. Dalam perkembangan selanjutnya, terjadilah perkawinan antara Silek Minangkabau dengan aliran bela diri yang dikuasai dan dibawa oleh setiap pengawal dari negeri asalnya itu (Maryono 1998:40),

Umumnya, silek di Minangkabau disesuaikan dengan nama daerah atau tempat aliran silek itu berkembang, seperti Silek Kumango, Silek Lintau, Silek Sungai Patai, Silek Pangian, Silek Sitaralak, Silek Sugiridiek, Silek Luncua, Silek Koto Anau, Silek Sungai Pagu, Silek Sunua, Silek Pasisia, Silek Bayang, Silek Paninjauan, Silek Pauh, dan Silek Gunuang. Adapun nama aliran silek yang diambil dari alam adalah Silek Unggan, Silek Gayuang Salacuik, Silek Jantan dan Batino, Silek Balam, Silek Harimau, Silek Rantau, Silek Ulu Ambek, Silek Alang, Silek Sacabiak Kapan, Silek Natal Gajah Dorong, Silek Lamo Alif, Silek Buah Tarok, Silek Buayo Lalok, Silek Ilau (Djamal, 2001:12).

Dalam masyarakat Minangkabau, silek mempunyai dua peranan. Pertama, silek sebagai seni bela diri dan dinamakan silek. Kedua, silek sebagai permainan yang dinamakan pancak. Pancak merupakan tangga atau satu tahapan awal dalam mempelajari silek. Para pasilek disebut dengan pandeka (pendekar), sedangkan pemain pancak disebut dengan anak sasian atau anak silek karena umumnya yang mempelajari pancak adalah remaja dan anakanak. Seorang pandeka mempunyai etika, musuah indak dicari, jikok basuo pantang diilakkan 'musuh tidak dicari kalau bertemu pantang dielakkan' (Navis, 1984: 267).

Dari sekian banyak jenis silek yang terdapat di Minangkabau, di Kabupaten Tanah Datar, tepatnya di kampung Kumango, terdapat silek yang disebut Silek Kumango. Silek Kumango adalah salah satu aliran silek 
yang cukup tua yang tumbuh dan berkembang dari dan di lingkungan surau. Silek Kumango dikembangkan oleh Syekh Abdurahman Al Khalidi yang dikenal sebagai Syekh Kumango. Perlu diketahui, Syekh Kumango ini adalah salah satu tokoh penting dalam penyebaran tarekat khususnya tarekat Samaniyah di Minangkabau. Banyak orang yang datang untuk mengambil baiat tarekat ke Surau Kumango ini. Sampai saat ini pun Surau Syekh Kumango menjadi pusat ziarah bagi para murid Tarekat Samaniyah yang ada di Minangkabau, Malaysia, Kalimantan, dan sekitarnya.

Adapun daerah yang menurut penulis sangat menarik untuk mengamati silek Kumango ini adalah Kecamatan Sungai Tarab, tepatnya di Kanagarian Rao-Rao. Nagari Rao-Rao merupakan suatu daerah tempat silek Kumango berkembang. Secara historis Tanah Datar adalah daerah yang maju sejak dahulu. Dapat dipastikan silek Kumango sudah ada sejak lama dan disosialisasikan kepada generasi muda.

Saat ini hanya segelintir orang yang mengetahui dan mengenal tradisi ini. Sementara itu, pewaris atau orang yang masih mengenal dan mengetahui tradisi ini semakin hari makin berkurang. Ironisnya, kaum muda bahkan ada yang tidak mengenal sama sekali. Kenyataan ini membawa kekhawatiran untuk masa yang akan datang. Ini berarti generasi muda sekarang tidak lagi mengenal kekayaan budayanya. Dengan demikian, jika tradisi ini tidak segera didokumentasikan, ia akan segera hilang seiring hilangnya para pelaku, tanpa dapat diketahui oleh para generasi muda.

\section{Metodologi}

Silek adalah representasi budaya Minangkabau. Kebudayaan dalam konteks ini dipahami sebagai sistem nilai yang mengarahkan perilaku. Penulisan ini menggunakan pendekatan etnografi. Etnografi merupakan pekerjaan mendeskripsikan suatu kebudayaan. Tujuan utama aktivitas ini adalah memahami suatu pandangan hidup dari sudut pandang penduduk asli ( Spradley 1997:3). Etnografi merupakan suatu bangunan pengetahuan yang meliputi teknik penulisan, teori etnografi, dan berbagai macam deskripsi kebudayaan. Budaya itu juga suatu sistem simbol yang mengandung makna dan untuk mengungkapkan makna simbol itu dilakukan melalui interpretasi.

Tugas utama etnografi adalah mendeskripsikan kebudayaan karena merupakan langkah pertama dalam memahami rumpun manusia. Deskripsi kebudayaan di satu sisi mendeskripsikan perbedaan-perbedaan dan di 
sisi lain menerangkannya. Penjelasan perbedaan kebudayaan sebagian tergantung pada pembuatan perbandingan lintas budaya.

Dalam melakukan kerja lapangan, etnografer membuat kesimpulan budaya dari tiga sumber: (1) dari yang dikatakan orang, (2) dari cara orang bertindak, dan (3) dari berbagai artefak yang digunakan orang. Masingmasing kesimpulan budaya hanya merupakan suatu hipotesis mengenai hal yang diketahui orang. Hipotesis ini harus diuji secara berulang-ulang sampai etnografer itu merasa pasti bahwa orang-orang itu sama-sama memiliki sistem makna budaya yang khusus.

Dalam metode etnografi terdapat hubungan antara agama dan budaya. Menurut Malefejit (dalam Agus: 1999) agama adalah salah satu aspek penting dari kebudayaan yang tidak hanya ditemukan dalam setiap masyarakat, tetapi juga berinteraksi secara signifikan dengan institusi budaya lain. Ekspresi religius ditemukan dalam budaya material, perilaku manusia, nilai, moral, sistem keluarga, ekonomi, hukum, politik, pengobatan, sains, teknologi, seni, pemberontakan, perang, dan sebagainya.

Persoalan-persoalan agama erat kaitannya dengan kebudayaan karena berhubungan dengan sistem ide, sistem nilai, sistem norma, sistem hukum dan tingkah laku. Kebudayaan dikembangkan oleh masyarakat dari ajaran agama yang bersangkutan dan dilaksanakan serta diyakini melalui hasil pemahaman rasa, cipta, dan tindakan.

Dengan demikian, silek merupakan sebagian kecil dari gejala kebudayaan. Sebagai bagian dari kebudayaan, silek tidak dapat terlepas dari sifat khas kebudayaan sebagai cerminan diri manusia pelakunya. Satu di antara sifat khas kebudayaan adalah simbolisme dan agama yang mengandung nilai-nilai.

Dalam penulisan ini, etnografi digunakan sebagai landasan untuk menjelaskan dan mendeskripsikan silek yang mengandung unsur-unsur sosial, agama, dan tata nilai kehidupan yang terdapat dalam masyarakat Minangkabau khususnya di Nagari Rao-Rao.

Pengumpulan data dilakukan dengan teknik observasi dan wawancara. Observasi dilakukan sebelum terjun ke lapangan untuk menghimpun data awal. Observasi dilakukan untuk peninjauan objek, pemilihan responden, dan sebagainya. Observasi ini sangat diperlukan untuk mengenal wilayah dan memeriksa kembali keabsahan data yang diamati.

Wawancara adalah salah satu cara pengumpulan data yang dilakukan melalui kegiatan komunikasi lisan dalam bentuk terstruktur, semi 
terstruktur, dan tidak terstruktur (Maryaeni, 2005: 70). Dalam pengumpulan data penulisan ini, penulis menggunakan wawancara tidak terstruktur. Penulis hanya berfokus pada pusat-pusat permasalahan tanpa diikat format-format tertentu secara ketat. Bentuk wawancara yang dilaksanakan bisa dalam bentuk individual dan kelompok. Sebagai interviewer, penulis melakukan wawancara secara directive, dalam artian penulis selalu berusaha mengarahkan topik pembicaraan sesuai dengan fokus permasalahan yang akan dipecahkan.

Untuk pemilihan informan, penulis mewawancarai informan kunci. Penulis hanya mewawancarai orang-orang yang berkompeten dan paham dengan objek penulisan serta pengguna langsung objek penulisan ini.

Data yang diperoleh dari teknik observasi dan wawancara kemudian dianalisis sesuai masalah penulisan. Analisis ini berusaha menjawab dan menjelaskan fenomena yang terdapat dalam tradisi Silek Kumango tersebut. Teknik analisis ini bermaksud menjelaskan gambaran secara mendetail tentang sifat dan karakteristik dari subjek yang menjadi pusat perhatian berdasarkan fakta yang tampak.

\section{Kanagarian Rao-Rao Tanah Datar, Sumatera Barat}

Kenagarian Rao-Rao terletak di lereng bagian timur Gunung Merapi pada ketinggian kira-kira 650-700 meter di atas permukaan laut. Kenagarian Rao-Rao termasuk ke dalam wilayah administrasi Kecamatan Sungai Tarab, Kabupaten Tanah Datar. Wilayahnya berbatas di sebelah utara dengan Kenagarian Koto Baru Kecamatan Sungai Tarab dan Salimpaung Kecamatan Salimpaung. Sebelah timur berbatas dengan Situmbuk Kecamatan Salimpaung dan Kumango Kecamatan Sungai Tarab. Sebelah selatan berbatas dengan Kenagarian Kumango dan Pasir Lawas Kecamatan Sungai Tarab. Batas alam kenagarian yang dapat dilihat adalah di sebelah timur berbatas Bukit Sibumbun dan di sebelah barat dengan lereng Gunung Merapi. Perbatasan utara dan selatan tidak kelihatan karena terletak di tanah yang datar yaitu berupa sawah dan tanah perladangan.

Tipografi daerah Rao-Rao berbukit berlembah dengan jurang yang curam dan dalam. Kenagarian Rao-Rao terbagi atas empat jorong, yaitu Jorong Pandiang Andiko, Jorong Carano Batirai, Jorong Lumbuang Bapereang, dan Jorong Balerong Bunta. 


\section{Asal-Usul Nagari Rao-Rao}

Nenek moyang masyarakat Rao-Rao berasal dari Gunung Merapi, begitulah sejarah atau asal-usul Nagari Rao-Rao. Sebagaimana yang dijelaskan oleh Dt. Marajo Basya (65), begitulah cerita yang diterimanya seorang turun temurun, sesuai warih nan ditarimo, pusako nan bajawek, dari niniek turun ka mamak, dari mamak turun ka kamanakan, (waris yang diterima, pusaka yang diterima, dari ninik turun ke mamak, dari mamak turun ke kemenakan) hingga sampai sekarang. Hal itu digambarkan sebagaimana dalam pantun di bawah ini.

\section{Dimano mulo titiak palito \\ Di baliak telong nan batali \\ Di mano mulo niniek kito \\ Iyo dipuncak Gunung Marapi \\ (Dimana mula titik pelita \\ Dibalik telong yang bertali \\ Dimana mula ninik kita \\ Ya dipuncak Gunung Merapi)}

Pantun di atas berisi persyaratan bahwa nenek moyang orang Minangkabau dan juga nenek moyang orang Rao-Rao berasal dari Gunung Merapi. Dari Gunung Merapi, mereka turun menuju Pariangan. Setelah penduduk Pariangan berkembang sedangkan luas tanah semakin sempit untuk bercocok tanam dan sumber kehidupan semakin sulit maka mulailah sebagian penduduk secara berombongan pergi meninggalkan Pariangan menuju ke arah Timur dan Utara, dengan menyusuri sungai yang akhirnya sampailah mereka di Rao-Rao.

Menurut Dt. Marajo Basya, nenek moyang orang Rao-Rao berasal dari daerah Pariangan. Kedatangan mereka di Rao-Rao tidak secara sekaligus, tetapi secara bertahap dengan jumlah yang kecil. Di tempat yang mereka tuju pertama kali itu, mereka membentuk taratak, yaitu dengan jalan memancang tanah-tanah untuk bertempat tinggal yang terdiri atas beberapa keluarga. Setelah berkembang, taratak membentuk dusun kemudian dusun meningkat menjadi koto. Akhirnya, dari koto terbentuklah suatu nagari yang kita kenal dengan Nagari Rao-Rao. Jadi, mereka datang ke Rao-Rao tidak sekaligus akan tetapi sedikit demi sedikit dengan jalan membentuk taratak dan perkembangannya itu secara berangsur-angsur. Mengenai adat yang 
dipakai di Kenagarian Rao-Rao ialah adat yang diterapkan dalam kelarasan Bodi Caniago (wawancara dengan Dt. Marajo Basya tanggal 28 Februari 2010).

\section{Sejarah Silek Kumango}

Satu di antara aliran silek yang tumbuh dan berkembang di Nagari RaoRao adalah Silek Kumango. Sesuai dengan namanya, Silek Kumango berasal dari nagari Kumango. Guru pertamanya adalah Syekh Abdul Rahman Alkhalidi yang karena kepandaiannya "basilek" beliau mendapat sebutan Syekh Kumango. Guru silek ini kemudian mempunyai anak yang bernama Ibrahim Panduko Sutan dan Syamsarif Malin Marajo.

Dalam perkembangan selanjutnya, dua anak Syekh Abdul Rahman Al-Khalidi ini berperan penting dalam mengembangkan silek Kumango. Mereka berdua dengan tekun membawa dan sekaligus mengembangkan silek tersebut. Pada tahun 1952, Syamsarif Malin Marajo berhasil menjadi juara pencak silat pada PON II di Jakarta. Keberhasilan inilah yang membawa harum nama silek Kumango di Sumatera Barat.

Pada masa itu silek betul-betul sebuah ilmu bela diri yang mampu mendudukkan seseorang pada kedudukan tertentu di masyarakat. Seorang ahli bela diri akan disegani dan dihormati baik oleh teman maupun lawan. Begitu pula dengan Syamsarif Malin Marajo, kharismanya yang begitu besar membuat dia sampai-sampai mempunyai kekuatan untuk menggerakkan massa di daerah tersebut. Penggerakan masa dikerahkannya dalam rangka mendukung pemberontakan PRRI pada tahun 1958.

Pada masa tersebut ada suatu ciri khas bagi masyarakat setempat yaitu jagoan silek kebanyakan adalah para kusir bendi. Kenyataan demikian memang tidaklah mengherankan pada masa itu, karena tugas kusir mengawal atau mengamankan penumpang yang sebagian besar pedagang. Daerah yang masih sepi dan melewati hutan menyebabkan para kusir bendi ini harus menjaga diri sehingga melengkapinya dengan bela diri silek.

Pada waktu senggang, para kusir ini juga melatih anak-anak didiknya. Biasanya mereka juga mempunyai sasaran (padepokan) sehingga pada waktu itu dapat dikatakan sebagai masa jaya silek di daerah Sumatera Barat pada umumnya dan di Rao-Rao khususnya.

Menurut Zurrahman, perkembangan sasaran ini terhenti ketika Syamsarif Malin Marajo diculik oleh PKI. Penculikan yang dilakukan PKI ini sekaligus menandakan pula bahwa Malin Marajo memang sebagai 
lawan berbahaya bagi PKI. Pengaruhnya yang sangat besar dapat dilihat melalui keahlian silek dan kebaikan budinya. Hal ini dibuktikan dengan banyaknya masyarakat yang percaya dengan sistem kepemimpinannya.

Meninggalnya Malin Marajo tidak menyebabkan hilangnya silek di Rao-Rao. Hal ini karena pengikut-pengikutnya yang sudah bisa diandalkan mampu mendirikan sasaran-sasaran baru dan terus mengembangkannya. Mereka menerima "anak sasian" (anak didik) baru dan mengajarinya, begitu seterusnya sehingga silek dengan pasang surutnya tetap masih ada sampai sekarang.

Pada masa sekarang di Nagari Rao-Rao, silek dipimpin oleh salah seorang guru tuo yang bernama Zul Rahman (46 tahun). Namun, perkembangannya tidak seperti dahulu. Pada waktu dahulu, hampir setiap orang tua mendorong anak dan kemenakannya untuk belajar ilmu beladiri. Sekarang sasaran silek kurang mempunyai murid disebabkan kurangnya minat dan perhatian orang tua terhadap anak kemenakannya dalam mepelajari ilmu silek (bela diri). Akibatnya jumlah murid di sasaran tersebut yang aktif hanya 5-10 orang. Tempat berlatih anak didik sekarang kurang memadai karena kondisi tempat berlatih guru tuo(guru tua) memprihatinkan sehingga tempat berlatih harus menumpang di halaman tetangga.

\section{Perkumpulan Silek dan Pemahamannya}

Aliran silek yang utama di Tanah Datar adalah Silek Kumango. Silek ini merupakan silek yang relatif lebih berkembang di daerah tersebut. Di samping silek Kumango masih ada beberapa silek yang hidup, tetapi jumlah anggotanya relatif sedikit dan tidak berkembang pesat seperti silek Kumango.

Hubungan antarsasaran (padepokan) di daerah tersebut dapat dikatakan tidak ada masalah dan masing-masing berkembang dengan tidak saling mempengaruhi. Gerakan-gerakan yang dimiliki setiap aliran mempunyai ciri khasnya masing-masing dan dengan ciri khasnya tersebut silek di daerah Tanah Datar berkembang. Setiap sasaran itu berkembang sendiri-sendiri, hingga kadang-kadang antar-sasaran yang satu dengan sasaran yang lain tidak saling mengetahui, terutama yang lingkupnya masih kecil. Hal ini karena tidak ada aturan atau ketentuan-ketentuan bagi seorang guru untuk memberitahukan sasaran-nya pada orang lain.

Menurut Zurrahman, pada zaman dahulu sasaran-sasaran yang dianggap besar mempunyai murid sampai puluhan orang dan mempunyai jadwal latihan di malam hari. Di antara murid dari sasaran yang satu dengan 
sasaran yang lain tidak pernah terjadi konflik. Begitu berkembangnya silek pada masa lalu sampai menjadikan silek sebagai ciri khas di Sumatera Barat pada umumnya.

Cara mengajar oleh seorang guru silek kepada muridnya dilakukan secara berjenjang. Dikatakan demikian, sebab seorang murid sasaran yang dianggap mampu melatih ia akan diberi kepercayaan untuk melatih adikadik yang yunior, tetapi latihan berjenjang hanya terbatas pada latihanlatihan pukulan dan gerakan-gerakan elak, sedangkan makna-makna yang terkandung di dalamnya tetap diberikan oleh guru tuo-nya. Dalam latihan, sekaligus akan diberikan berbagai nilai-nilai luhur yang berfungsi sebagai pegangan hidup. Pelatihan silek dipilih waktu malam hari sebab merupakan saat yang tenang dan hening sekaligus dapat memfokuskan fikiran dari segala macam yang mengganggu, misalnya aktifitas keseharian, permasalahan dalam keluarga, dan lain sebagainya.

Tempat sasaran biasanya menggunakan tempat terbuka dan tidak ada yang ditutupi. Setiap orang diperbolehkan untuk melihat. Walaupun terbuka, silek tidak bisa dikuasai hanya dengan melihat tanpa belajar. Pepatah mereka menyatakan tau dirupo urang mancaliak, tahu diraso urang mamakan (tahu wajah karena melihat, tahu rasa karena memakan). Dalam pepatah ini terkandung makna bahwa setiap gerakan dalam silek tidak bisa dipelajari hanya dengan melihat. Walaupun berulang kali melihat, tetapi bila tidak mengikuti latihan-latihan maka mustahil akan pandai. Orang mungkin dapat meniru bentuk gerkan-gerakannya, tetapi tidak akan bisa melakukannya dengan benar.

Adanya nilai-nilai tersebut menyebabkan tidak ada rasa curiga antarsasaran. Kepercayaan antarsasaran merupakan landasan untuk tetap saling percaya. Dengan demikian, rasa untuk tidak mencampuri apa yang dikerjakan orang lain merupakan kunci yang penting untuk menjaga keharmonisan antarsasaran.

Dahulu silek benar-benar dipakai sebagai salah satu sarana pembentukan watak dan mental. Anak sasian akan merasa dirinya lemah dan tidak mengerti apabila mengikuti latihan silek pada sasaran yang lain. Dalam perkembangan terakhir ini, silek hanya dipakai sebagai olah tubuh dalam arti kesenian dan kadar ilmu bela dirinya cenderung sudah jauh berkurang.

Pada masa lalu orang benar-benar akan dihormati apabila dia pandai basilek. Kedudukan di masyarakat akan betul-betul terangkat. Pada masa 
kini, silek benar-benar tidak berkaitan dengan kedudukan di masyarakat. Walaupun silek masih digeluti oleh sebagian generasi muda, tetapi bobotnya tidak setinggi dahulu, dalam arti tidak akan mengangkat harga dirinya di masyarakat.

\section{Sistem Pewarisan Silek Kumango}

Keterampilan silek tidak dapat diperoleh dengan hanya mempelajari gerakan saja, tetapi harus pula mempelajari arti atau kegunaan gerakan itu dalam kehidupan sehari-hari. Oleh karena itu, latihan gerakan-gerakan dalam silek harus didampingi oleh guru. Hal ini diperlukan karena seorang guru juga sekaligus mengisi pikiran atau pengetahuan anak didik atau muridnya dengan nilai-nilai luhur yang menjadi filosofi silek itu. Hal ini ditujukan untuk menjaga agar keterampilan silek tidak disalahgunakan dalam kegunaannya.

Bila dilihat dari nilai-nilai yang disampaikan dalam latihan silek, seorang guru tuo akan menekankan supaya hasil pelatihan silek tersebut dapat digunakan untuk mencari kawan, kesehatan badan, menguatkan kemauan, dan mendekatkan diri terhadap Tuhan Yang Maha Esa. Semua nilai tersebut akan terus menerus diungkapkan dan diulang-ulang sebab pelatihan silek pada dasarnya bukan hanya keterampilan bela diri, tetapi yang lebih penting adalah mempersiapkan mental anak didiknya.

Dari hasil pelatihan silek akan terlihat bahwa semakin tinggi tingkat keterampilan anak didik tersebut maka anak didik semakin bisa membawa diri, baik dalam tindakan maupun percakapan. Kenyataan tersebut seperti makna peribahasa "padi semakin berisi maka akan makin merunduk". Seorang anak didik yang telah bisa memahami silek diharapkan mampu mengendalikan emosi dan dapat membawa diri dari segala situasi yang berkembang.

Saratnya nilai dan banyaknya jumlah murid yang harus dilatih menyebabkan seorang guru harus selalu mendampingi murid-muridnya. Walaupun demikian, kadang karena keterbatasan tenaga, dapat pula latihan keterampilan diperagakan oleh murid senior. Kemandirian yang dilatihkan guru tersebut sebenarnya mempunyai makna positif dalam perkembangan silek itu sendiri sebab di satu sisi seorang anak didik senior sudah diajarkan melatih agar yunior akan lebih menghormati dan menghargai seniornya.

Dengan proses yang demikian, seorang guru dapat melihat semua anak didiknya yang berlatih. Apabila ada yang melakukan kekeliruan 
gerakan, seorang guru tuo selalu turun memberikan pengarahan bahkan contoh-contoh gerakan yang benar dan menjelaskan akibat-akibat yang timbul dari kesalahan tersebut. Dalam memberikan latihan, seorang guru tidak akan membedakan antara saudara dan orang lain. Mereka akan diberi latihan yang sama sehingga perbedaan tingkat kepandaian murid akan lebih ditentukan oleh daya serap dari masing-masing anak didiknya.

Sistem pelatihan silek Kumango dapat dikatakan demokratis. Hal ini sesuai dengan struktur pemerintahan tradisional Minangkabau yang juga memperhatikan nilai-nilai di dalam adat Minangkabau. Dalam perguruan tidak harus menuruti setiap gerakan yang diberikan oleh seorang guru. Dengan kata lain, seorang murid dapat membantah atau mengajukan keberatan atas gerakan yang diajarkan gurunya bila dirasakan tidak menguntungkan. Untuk menjelaskannya akan terjadi diskusi antara guru dan anak sasian sekaligus peragaan untuk membuktikan hasil yang didapat dari gerakan tersebut. Misalnya, dengan cara memperagakan dan memberi penjelasan akibat dari suatu pukulan secara langsung maka anak didik benar-benar akan memahami manfaat dan kelemahan dari suatu gerakan.

Menurut Zurrahman pada masa lalu ada konsep yang cenderung menghambat perkembangan silek. Konsep yang kurang mendukung itu adalah nan sapacik indak diagiahkan (sebagian kecil dari ilmu tidak boleh diberikan atau diajarkan kepada anak didiknya). Konsep tersebut muncul karena adanya kekuatiran anak didik yang dilatihnya akan dapat mengalahkan gurunya. Oleh karenanya, setiap generasi akan kehilangan paling sedikit satu gerakan. Inilah dalah satu penyebab semakin merosotnya kualitas silek itu sendiri. Untungnya, para guru sekarang sudah sadar bahwa nilai-nilai yang demikian patut diabaikan. Silek Kumango di Nagari Rao-Rao tidak lagi memakai konsep tersebut.

Suatu hal yang sangat menonjol pada silek Kumango khususnya dan silek di Sumatra Barat pada umumnya adalah keterkaitannya dengan agama Islam. Landasan yang kuat dalam hal keagamaan merupakan kunci utama dalam mempelajari silek Kumango. Oleh karena itu, berlatih silek sekaligus akan membimbing seseorang pada sikap yang baik, seperti menjauhkan pesilek dari sifat takabur, durhaka, dan sombong yang merupakan ajaranajaran yang dilarang agama. Begitu pula seorang pesilek akan dilarang keras untuk berniat atau bermaksud berbuat jahat kepada orang lain. Nilai-nilai tersebut terkandung dalam ungkapan "baniat mamatah tapatah" (berniat mematah terpatah) yang berarti barang siapa yang berniat jahat dia sendiri $\underline{\underline{\text { yang celaka. Nilai-nilai yang demikian sangat relevan dengan bela diri }}}$ 
tersebut.

Di samping itu, mereka percaya bahwa bila seorang pesilek melakukan perbuatan jahat maka akan diberikan suatu peringatan oleh Tuhan, biasanya berupa makhluk halus yang muncul seperti harimau. Keyakinan itu didasari oleh pandangan bahwa segala yang dilakukan dalam silek adalah sesuatu yang suci sehingga harus menjauhkan diri dari perbuatan-perbuatan kotor. Oleh karena itu, setiap sebelum latihan mereka selalu melakukan untuk meminta perlindungan Tuhan Yang Maha Esa.

Secara singkat, sistem pelatihan silek kepada anak didik memiliki empat tahap. Pada tahap pertama, yang dipelajari adalah batangnya. Pada tahap ini diajarkan cara melangkah dan cara menangkisnya. Bagaimana melakukan kuncian, melakukan sapuan, bagaimana sikap kalau terkunci dan bagaimana pula cara menjatuhkan dan lain sebagainya.

Tahap kedua, setelah mempelajari batang adalah mempelajari "hiduik salampih (hidup selapis)". Pada tahap dipelajari gerakan antisipasi kalau serangan pertama ditangkis lawan, bagaimana melepas kuncian dan sekaligus melakukan serangan balasan atau balik mengunci. Pada tahap ini gerakan dasar yang dipelajari semula dipecah menjadi beberapa gerakan. Satu gerakan dasar dapat dipecah menjadi tidak kurang dari lima macam gerakan.

Pada tahap ketiga, adalah pelajaran "hiduik duo lampih (hidup dua lapis). Tahap ini belajar menangkis sekaligus melakukan serangan atau kuncian. Pada tahap ini sudah mulai tampak bentuk perkelahian dalam arti saling melakukan serangan dan kuncian.

Bila semua pelajaran dari tahap pertama sampai tahap ketiga sudah dikuasai maka pada tahap keempat merupakan tahap pemantapan dari hasil latihan sebelumnya. Pada tahap ini seorang pesilek sudah bisa menggunakan segala macam gerak yang dalam aturan setempat bernama "cancang talandeh jadi ukia" (semua gerakan dapat dilakukan asal tidak menyimpang dari hukum-hukum dasar). Dengan demikian, berarti dalam tahap ini seorang pasilek dituntut kreativitasnya untuk dapat mengembangkan dirinya. Di sinilah tingkat kepandaian pesilek akan berbeda satu sama lain. Bagi mereka yang mempunyai kreativitas yang tinggi maka ia akan lebih mampu mengembangkan hasil latihan secara maksimal.

Untuk kategori pasilek yang sudah mahir, ia akan menggunakan raso (rasa). Pasilek dapat disebut pasilek bila sudah mempunyai raso. Seseorang dikatakan sudah punya raso apabila gerakkannya berlangsung 
secara refleks. Begitu pula dengan gerakan lawannya, ia sudah dapat membaca gerakan-gerakan yang akan dilancarkan lawannya. Tetapi untuk memunculkan raso ini diperlukan banyak latihan sehingga tidak ragu-ragu dalam mengantisipasi serangan lawan.

Pada tahap-tahap akhir, pasilek juga dilatih untuk memakai senjata tajam, baik pisau maupun golok. Tujuannya adalah agar pasilek terlatih mengantisipasi lawan dan serangan dengan senjata tajam.

Pada tahap akhir pelatihan silek, tidak ada upacara-upacara khusus yang menunjukkan bahwa seseorang sudah tamat dalam pelatihan silek. Namun demikian, ada suatu kekhasan bagi pasilek yang sudah dalam tingkat tinggi ini yaitu tidak semua jurus yang dikuasai secara sempurna, tetapi tiap murid memiliki keistimewaan masing-masing. Keistimewaan ini sangat ditentukan oleh faktor pasilek, misalnya ada yang sapuannya baik, ada yang kuncinya, ada kelincahannya, dan lain-lain. Hal ini merupakan bagian dari keunikan dalam mempelajari silek.

\section{Kearifan Lokal dalam Fungsi Silek Kumango}

Kearifan lokal dapat didefinisikan sebagai kebijaksanaan atau nilainilai luhur yang terkandung dalam kekayaan-kekayaan budaya lokal berupa tradisi, petatah-petitih dan semboyan hidup.

Di Sumatra Barat, silek merupakan keterampilan untuk membela diri tanpa menggunakan senjata atau alat lainnya. Dalam usaha bela diri dari serangan musuh maka silek diajarkan tanpa menggunakan alat, melainkan sepenuhnya berpegang pada keterampilan untuk mempertahankan diri dari segala serangan. Belajar silek bukan untuk mencari musuh, melainkan untuk mencari teman. Hal ini sesuai dengan pepatah musuah indak dicari, basuo pantang dielakkan. Maksudnya musuh tidak dicari, bertemu pantang dielakkan. Kalimat ini adalah kalimat pertama yang diucapkan guru gadang (guru besar) terhadap muridnya yang dipegang teguh oleh anak sasian.

Agar ada keyakinan dalam diri pada saat pergi atau pulang dari surau, maka para lelaki yang ada di desa-desa belajar silek. Selain rutinitas perjalanan dari rumah ke surau silek juga untuk bekal merantau. Rantau adalah tempat untuk mencari kehidupan dan penghidupan nantinya, karena dengan merantau akan meningkatkan harga diri dan martabat kaum kerabat dalam masyarakat. Hal ini karena sebagai laki-laki muda atau bujang, status sosialnya dipandang rendah dan tidak sempurna bagi masyarakat. Dia tidak diikutsertakan dalam perundingan keluarga. 
Untuk meninggikan derajat hidupnya dalam keluarga, merantau adalah salah satu jalannya. Biasanya dalam perjalanan merantau atau di tempat perantauan sering terjadi rintangan. Agar dalam perjalanan merantau hingga sampai di tempat perantauan ada keyakinan maka para orang tua atau mamak sangat menganjurkan kepada anak dan kemenakan untuk belajar silek.

Satu hal yang menarik dalam penggunaan silek di rantau adalah bila suatu saat dihadang oleh serangan musuh, pasilek tidak diperkenankan untuk menangkis pukulan lawan sampai yang keempat. Pukulan pertama dari musuh tidak boleh ditangkis karena menghormati ibu kandung yang melahirkan (orang tua perempuan). Pukulan kedua tidak boleh ditangkis karena menghormati bapak (orang tua laki-laki). Pukulan ketiga tidak boleh ditangkis karena menghormati guru yang telah mengajarkan silek. Pukulan yang keempat juga tidak boleh ditangkis karena menghormati teman karib. Pada pukulan yang kelima barulah boleh menangkis serangan musuh karena pada pukulan yang kelima musuh dianggap sudah kemasukan setan, sehingga setan yang ada didalam tubuhnya itu harus ditundukkan.

Tangkisan atau pukulan yang kelima bukan berarti harus menyakiti pihak musuh, melainkan masih berupa nasehat. Secara kasat mata musuh itu adalah lawan, tetapi secara batin adalah kawan (saudara) sehingga harus diselamatkan. Dengan demikian, hakekat tujuan silek Kumango adalah mencari persahabatan, mencari kawan tidak terbatas hanya di lingkungan Sumatera Barat.

Secara singkat fungsi Silek Kumango bagi pengikutnya adalah sebagai berikut.

\section{Untuk Membela Diri dan Mengendalikan Diri}

Kedatangan seorang murid (anak sasian) kepada seorang guru silek tentu didasari berbagai pertimbangan. Seorang murid ada yang melihat silek dari unsur olah raganya (kesehatan), ada yang melihat dari unsur seni, dan ada juga yang melihat dari unsur spiritual. Hal ini karena secara filosofis, silek berfungsi untuk mencari kawan, untuk olah raga, dan untuk menambah keimanan (mendekatkan diri kepada Tuhan).

Tidak semua murid mempunyai keseriusan yang sama dalam belajar silek. Oleh karena itu, tidak semua murid bisa menamatkan dirinya secara sempurna. Dengan kata lain, tidak semua murid mampu mencapai pengetahuan setara dengan guru gadang.

Dengan fungsi tradisionalnya sebagai ilmu bela diri, silek Kumango 
telah menarik hati sebagian kaum muda (laki-laki maupun perempuan) di Nagari Rao-Rao, untuk mendaftarkan diri pada seorang guru gadang atau guru tuo yang membuka sasaran tersebut. Kedatangan mereka ingin menjadi anak sasian agar dapat memperoleh latihan keterampilan fisik. Hal itu sangat mereka perlukan sebagai alat pertahanan diri bila suatu saat diserang oleh lawan. Dengan memperoleh keterampilan silek, mereka dapat menghindar maupun menangkis serangan musuh yang mengancamnya.

\section{Memantapkan Keimanan}

Esensi kemanusian adalah kebaikan. Semua hasil karya yang disebut kebudayaan pada hakekatnya merupakan cipta kebaikan manusia. Itulah sebabnya kebudayaan selalu berimplikasi dengan nilai moral dan sosial. Latar belakang penciptaan silek sebagai salah satu unsur budaya tradisional juga memiliki maksud yang sama yaitu berimplikasi moral dan sosial.

Dalam masyarakat Rao-Rao, secara makro dapat dikatakan unsur nilai moral dan sosial bersumber dari syariat Islam karena syariat Islam sudah berakar di dalam pola kehidupan mereka sehari-hari. Hal ini dimungkinkan karena penduduk Sumatera Barat umumnya di Nagari RaoRao khususnya termasuk penganut Islam yang taat. Hal ini tercermin pada ungkapan Adat basandi syarak, syarak basandi kitabullah. Pada ungkapan adat yang lain juga disebutkan, syarak mangato, adat mamakai (syarak mengatakan, adat memakai), artinya semua kebiasaan (adat) yang dilaksanakan dalam masyarakat sehari-hari berdasarkan kepada ajaran agama Islam.

Dari uraian di atas dapatlah kiranya dikatakan bahwa silek sebagai unsur kebudayaan yang ditemukan pada suku Minangkabau senantiasa berhubungan dengan nilai moral keislaman.

3. Harmoni Keluarga dan Masyarakat.

Ketika mamak masih menjadi pusat orientasi keluarga luas, setiap pendiri sasaran harus mendapat izin atau restu mereka. Hal ini karena mamak memegang peranan yang penting dalam kaumnya. Mamak adalah sosok yang menentukan di dalam persukuannya seperti kata pepatah Minangkabau mamak mambuang jauh, menggantuang tinggi. Artinya, mamak memiliki kewenangan yang besar terhadap saudara perempuannya beserta anak-anaknya.

Walaupun garis keturunan orang Minangkabau berdasarkan garis ibu, yang berkuasa di dalam kesatuan tersebut adalah laki-laki saudara ibu, yaitu mamak. Hanya saja kekuasaannya didasarkan atas mufakat seperti bunyi pepatah Minangkabau kamanakan barajo ka mamak, mamak barajo ka 
pangulu, pangulu barajo ka mufakat. Artinya kemenakan turut kepada mamak, mamak turut kepada pangulu, pangulu turut kepada mufakat

Mamak adalah pengurus dalam pengembangan harta pusaka yang dimanfaatkan sebesar-besarnya untuk kesejahteraan kaumnya. Di pihak lain, mamak mempunyai komitmen dalam memegang status sebagai mamak. Alangkah baiknya bila seorang mamak untuk menambah kewibawaan dan keamanan harta pusaka dengan dibekali keterampilan silek.

Para mamak biasanya mendukung ketika didirikan sebuah sasaran oleh seorang guru gadang karena silek Kumango sifatnya kekeluargaan. Menurut informasi informan, silek Kumango dalam menerima anak sasian tidak memandang status ekonomi. Berdasarkan pengamatan di lapangan terbukti anak sasian yang terbanyak berasal dari masyarakat yang status sosial ekonominya rendah.

Dalam mengasuh anak sasian, perguruan silek Kumango yang berada di Nagari Rao-Rao tidak mewajibkan membayar uang latihan untuk honor guru. Hal ini akan berlangsung sampai anak sasian menguasai keterampilan silek. Antara guru dan anak sasian terjalin suatu hubungan persaudaraan yang intim dan sukar untuk dinilai dengan uang. Proses ini berjalan dengan mempedomani pepatah raso jo pareso, lamak dek awak katuju di urang, maksudnya anak sasian tidak diwajibkan membayar dengan uang untuk biaya belajar, tetapi dengan bentuk lain sesuai kesanggupan dan kesadarannya. Misalnya, anak sasian membantu gurunya dalam mengerjakan pekerjaan sehari-hari, seperti pekerjaan pertanian atau pekerjaan yang lain yang merupakan usaha guru dalam menghidupkan keluarganya

Untuk menyemarakkan suasana latihan, kadang-kadang ada beberapa anak sasian yang membawa makanan sekadarnya. Seandainya anak sasian tidak ada yang membawa sesuatu untuk latihan, biasanya guru yang menyediakan air minum, rokok, dan penerangan. Hubungan antara anggota perguruan bukanlah hubungan yang berdasarkan materi melainkan berlandaskan rasa sadar dan tanggung jawab moral masingmasing tanpa ikatan formal.

Para orang tua maupun para mamak mengharapkan jiwa kekeluaragaan yang didapat dari perguruan silek agar dijadikan landasan hidup dalam keluarga oleh anak kemenakan di kemudian hari. Jika seorang anak sasian mampu memahami hakikat silek Kumango tersebut, niscaya ia akan bisa hidup damai dengan anggota keluarga dan masyarakat. 


\section{Kearifan Lokal dalam Simbol-Simbol}

Filosofi dalam SilekKumango antara lain dimulai pada saat penerimaan murid baru (mangangkat anak sasian) dengan kewajiban memenuhi syaratsyarat tertentu yang disebut manatiang syaraik (mengangkat syarat/ sumpah), yaitu:

a. lado jo garam (cabai dan garam), simbol agar ilmu yang diperoleh akan melebihi pedasnya cabai dan asinnya garam,

b. pisau tumpul, simbol bahwa murid yang baru datang diibaratkan sebagai pisau tumpul yang akan diasah di sasaran agar menjadi tajam,

c kain putiah/kain kafan, simbol kepasrahan kepada Sang Khalik agar selalu siap utuk kembali kepada-Nya,

d jarum panjaik jo banang (jarum penjahit dan benang), simbol efisiensi, hemat, dan tidak boros,

e bareh sacupak (beras 5 liter), simbol untuk bekal agar mandiri.

Sebagaimana sebagian besar silek Minangkabau lainnya, dalam pola geraknya (langkah) Silek Kumango juga menganut sistem langkah nan ampek (langkah empat). Pola langkah empat ini pada dasarnya adalah membagi ruang di sekeliling kita menjadi empat bagian, depan, belakang, kiri, dan kanan. Pola ini banyak ditemui di banyak aliran beladiri lainnya. Dalam Silek Kumango, langkah ampek ini disimbolkan sebagai langkah Alif, Lam, Lam, Ha dan Mim, Ha, Mim, Dal, yang merupakan huruf Hijaiyah yang merangkai kata Allah dan Muhammad.

Langkah nan ampek ini adalah bagian dari pituah filosofis orang Minangkabau yang biasa disebut sagalo nan ampek. Dalam menghadapi orang atau anak yang susah untuk diatur, para orang tua Minangkabau suka mengatakan indak tau nan ampek (tidak tahu yang empat) kepada anakanaknya. Ungkapan itu merupakan sindiran bahwa dia tak tahu tentang yang empat itu atau tidak beretika.

Konsep nan ampek dalam budaya Minangkabau meliputi banyak aspek seperti berikut.

Ampek macam batang aka:

Partamo syariaik

Kaduo tarikaik

Katigo hakikaik 
Kaampek makripaik

(Empat macam batang akar:

Pertama syariat

Kedua tarikat

Ketiga hakikat

Keempat makrifat)

Urang nan ampek:

Golongan partamo niniak mamak

Kaduo cadiak pandai

Katigo alim ulamo

Kaampek bundo kanduang

(Orang yang empat:

Golongan pertama ninik mamak

Kedua cerdik pandai

Ketiga alim ulama

Keempat Bunda kandung)

Adaik nan ampek:

Partamo adaik nan sabana adaik

Kaduo adaik nan diadaikkan

Katigo adaik nan taradaik

Kaampek adaik istiadaik

(Adat yang empat:

Pertama adat yang sebenar adat

Kedua adat yang diadatkan

Ketiga adat yang teradat

Keempat adat istiadat)

Langkah nan ampek ini juga disimbolkan dengan sifat dari Nabi Muhammad SAW, yaitu Siddiq, Tabligh, Amanah dan Fatonah. Siddiq artinya benar, Tabligh artinya menyampaikan, Amanah artinya percaya, Fatonah artinya cerdas. Masih banyak lagi filosofi Minangkabau yang terangkum dalam sagalo nan ampek (segala yang empat) ini yang tidak bisa disebutkan di sini.

Dari sisi ilmu batin, langkah nan ampek ini juga merupakan simbol nafsu manusia yang terdiri dari nafsu ammarah, lawwamah, sufiyah, dan 
muthmainah. Hal ini juga merupakan awal ilmu untuk mencari saudara batin guna mencari diri yang sejati. Ini mirip dengan pemahaman sedulur papat lima pancer yang ada di dalam budaya Jawa. Dengan konsep itu diharapkan anak sasian pada akhirnya akan menemukan jati diri sebagai manusia yang benar-benar manusia. Sehubungan dengan itu, empat tingkatan jenis manusia menurut pemahaman Minangkabau yang juga terangkum dalam empat bagian, yaitu: urang, urang nan taka urang, urang nan ka jadi urang, urang nan sabana urang.

Selain langkah ampek, dalam silek Minangkabau juga dikenal filosofi langkah tigo, yang memiliki muatan filosofis serupa dengan langkah nan ampek. Bila langkah ampek memiliki muatan agama, sebaliknya langkah tigo memiliki muatan adat, yaitu landasan pola pikir masyarakat Minangkabau.

Filosofi nan tigo dalam adat Minangkabau terepresentasi dalam ungkapan berikut.

Adaik babarih babalabeh

Baukua jo bajangko

Tungku nan tigo sajarangan

Patamo banamo alua jo patuik

Kaduo banamo anggo tanggo

Katigo banamo raso pareso

Alua jo patuik

Adat berbaris babalabeh

Berukur dan berjangka

Tungku yang tiga tumpuan

Pertama bernama alur sama patut

Kedua bernama anggaran tangga

Ketiga bernama rasa periksa

Alur dan patut

Arti filosofi di atas adalah logika, anggo tanggo (anggaran tangga) kedisiplinan, dan raso jo pareso (rasa dan periksa) yakni pertimbangan perasaan/olah rasa dan ketelitian/periksa. Aplikasinya dalam ilmu silek, silek harus sesuai dengan ilmu pengetahuan, logika, dan masuk akal. Dalam mempelajarinya diperlukan kedisiplinan dan yang tak kalah penting adalah pengolahan rasa untuk mempertajam kepekaan.

Dalam Silek Kumango, pengaruh sufistik dari Syekh Abdurahman 
juga tampak dalam filosofi setiap serangan haruslah dielakkan terlebih dahulu. Tidak tanggung-tanggung, keharusan mengelak tidak hanya sekali melainkan empat kali.

Elakan pertama disimbolkan sebagai elakan mande dan digunakan untuk menghadapi serangan pertama dari seorang musuh. Elakan mande disimbolkan sebagai nasihat dari seorang ibu kepada anaknya sehingga kita wajib memahaminya dan bukan melawannya.

Elakan kedua disimbolkan sebagai elakan ayah dan bukan dilawan. Elakan ketiga, disimbolkan sebagai elakan guru. Maksudnya kita harus mengumpamakan bahwa itu adalah seorang guru yang sedang menegur sehingga wajib memahami dan tidak dibalas dengan serangan. Elakan keempat disimbolkan sebagai elakan kawan yang diartikan bahwa serangan itu adalah seorang teman yang ingin bermain sehingga harus dipahami dan berusaha jangan terpancing emosi.

Pada serangan kelimalah seorang pasilek Kumango dapat melakukan gerakan perlawanan atau membalas. Pada serangan kelima ini, si penyerang diibaratkan sudah bersama setan sehingga wajib untuk menyadarkannya. Dalam aplikasi gerakan silek ini, bisa dilakukan dengan gerakan serangan berupa pukulan atau sapuan kaki yang diakhiri dengan kuncian. Walaupun demikian, perlu diingat bahwa serangan tidak ditujukan mencederai lawan. Bahkan, apabila lawan sampai kesakitan, minta maaf adalah hal yang patut dilakukan.

Ketika lawan sudah jatuh, pasilek Kumango tidak boleh terus menyerang. Dalam pepatah Minangkabau, hal ini disimbolkan dengan alah kanyang ka tambah (telah kenyang mau menambah). Lawan yang sudah jatuh tidak sepatutnya dilukai lagi. Menyerang lawan yang sudah jatuh bisa mengakibatkan posisi pasilek menjadi lemah. Sebaiknya, lawan dibiarkan sampai berdiri kembali. Demikianlah beberapa makna filosofis dari silek Kumango.

\section{Penutup}

Silek kumango diciptakan oleh Syekh Abdul Rahman Al Khalidi di Kampung Kumango. Syekh Abdul Rahman Al Khalidi menciptakan silek Kumango bukan hanya sekedar sebagai bela diri dan seni gerak. Lebih dari pada itu, berkaitan dengan upaya mengenali diri di jalan Allah, sejalan dengan ajaran Islam. Syarat yang harus dipenuhi oleh anak sasian adalah persyaratan materi dan non materi. Persyaratan non materi adalah budi, 
mumaiz, jenis kelamin, dan Islam. Persyaratan material adalah kain putih dua potong, cabe merah, garam, pisau, jarum dan benang.

Silek Kumango berfungsi untuk membela diri, memantapkan keimanan, harmoni keluarga, dan masyarakat. Dalam silek Kumango, pengaruh sufistik dari Syekh Abdurrahman Al Khalidi juga tampak dalam filosofi bahwa setiap serangan haruslah dielakkan terlebih dahulu. Keharusan mengelak tidak saja sekali melainkan dielakkan sebanyak empat kali yaitu elakan pertama disimbolkan sebagai elakan mande, elakan kedua elakan ayah, elakan ketiga elakan guru, elakan keempat elakan kawan, elakan kelima elakan perlawanan. Semua itu merupakan kearifan lokal Minangkabau yang terkandung dalam silek Kumango

\section{DAFTAR PUSTAKA}

Agus, Bustanuddin. 1999. Antropologi Agama. Padang. FISIP UNAND

Djamal, Emral. 2001. Galanggang Silih Baganti IPSI Sumbar. Presentasi Konsep dan Peraturan. IPSI Padang

Maryaeni. 2005. Metode Penulisan Kebudayaan. Jakarta: Bumi Akasara.

Maryono, O'ong. 1999. Pencak Silat Merentang Waktu. Yogyakarta: Yayasan Galang

Navis, A.A. 1984. Alam Terkembang Jadi Guru. Jakarta: Pustaka Grafitipers. Spradley, James,P. 1997. Metode Etnografi (diterjemahkan oleh Misbah Zulfa Elizabeth). Yogyakarta. Tiara Wacana. 
